DOI: $10.1515 /$ ausp-2015-0018

\title{
English for Special Purposes: Specialized Languages and Problems of Terminology
}

\author{
Imola Katalin NAGY \\ Department of Applied Linguistics \\ Sapientia Hungarian University of Transylvania (Târgu Mureş, Romania) \\ nimolkat@gmail.com
}

\begin{abstract}
This paper deals with some aspects of English for professional purposes. After a short historical overview of theories related to LSP (language for special purposes), we focus on some of the linguistic peculiarities of English for Specific Purposes. Our aim is to make a synthesis of the main theories and debates upon the issue of specialized languages, as the number of articles and writings on the topic is tremendous. We also wish to make a brief presentation of the most important contributions (still, we have to admit that the list of authors and articles is much longer, we had to make a selection, due to the editorial limitations of this article). We have gathered and synthesized what authors like Cabré, Celce-Murcia, Crystal, Croitoru, Motos, Strevens and others have said and we have also tried to make a comprehensive list of the names given to specialized language or language for specific purposes over time. Still, we have to state that it is not our goal to come up with examples or conclusions regarding our own personal ESP experience and/or previous research. The goal of this present study is to make a synthesis of the theories and writings on the topic of English for specific purposes (i.e. metaelemzés/metaanalysis in Klaudy's words or szekunder kutatás/secondary research in Fóris's words).
\end{abstract}

Keywords: specialized languages, English for special or specific purposesESP, linguistic features, terminology

\section{Introduction}

English for Specific Purposes has been developed to meet the needs of those learners who intend to use English in professional contexts and for professional purposes. Languages for specific purposes, or, in this case, English for Specific Purposes (hereinafter referred to as ESP) can be dealt with from at least two perspectives: on the one hand, from a didactic perspective, as ESP is a sphere of language teaching. On the other hand, we must approach the issue of specialized language(s) from a linguistic viewpoint, as English for Specific Purposes is 
a peculiar segment of language, with its major component - terminology, to which some authors add the science specific grammar, i.e. linguistic issues and particularities. In this article, we intend to cover the most important theories and approaches of ESP and special languages, implicating both didactic and linguistic peculiarities. The first part of the article is dedicated to the evolution of the didactic aspects of ESP, while the second part deals with some of the most important approaches to the linguistic peculiarities of English for Specific Purposes over the past decades.

The first major issue is connected to the plurality of names given to what we call here English for Specific Purposes. In English several terms are used, among which specialized languages, special languages, specialized communication, technical English, scientific English, English for special or specific purposesESP, English for Occupational Purposes, Professional English or, more recently, Academic and Professional Languages. In Romanian, researchers use the following names: limbaj specializat, limbaj profesional, comunicare specializată, comunicare profesională, tehnolect, while in Hungarian there are two competing terms, szaknyelv and szakmai nyelvhasználat (see Kurtán 2003).

\section{The historical background of English for Specific Purposes}

The history of the ESP (English for Specific Purposes) movement can be traced back to the 1960s, though several books and materials designed to teaching English for specialists in different fields (especially business and economics) were published even in the first decades of the $20^{\text {th }}$ century. As Marianne CelceMurcia (1991) puts it, "almost 30 years ago, ESL/EFL practitioners in many parts of the world began to convene on order to discuss the development of systematic analyses of students' needs, particularly as they related to the features of the English that students must employ in the real world." (Celce-Murcia 1991: 67)

There are four important phases in the history and development of the ESP movement. The first phase covers the 1960s and 1970s, when teaching ESP focused on the sentence-level. The needs analyses that were carried out concentrated on the lexical and grammatical features of professional registers, such as the language of engineering or the language of law. Researchers discovered, among the most striking characteristics of EST (English for Science and Technology), for instance, the extensive use of Present Tense Simple, of passive constructions and of noun compounds. In what Business English was concerned, the focus was on the rules of writing business letters, rules that stated the use of a set format, formulaic expressions, a limited set of vocabulary and conjunctions. "After careful analyses of identified spoken or written discourse, practitioners organized their grammar- 
based curricula around the features of these special registers. One of the most famous volumes to appear during this period was Swales's Writing Scientific English (1971), where chapters are based principally upon the grammatical forms most commonly found in the scientific English register." (ibid. 68)

The late 1970s and early 1980s brought about the second phase in the career of ESP, in which the sentence level analysis and the focus on grammatical forms started to integrate rhetorical functions as well. In 1981 Tarone et alii (1981) published a study that intended to examine the function and frequency of passive voice within astrophysics. When comparing the functions of passive structures in these astrophysics journal articles with active voice, they practically performed a rhetorical analysis, stating that passive voice was used by the scientists/ authors of the articles when "a. they are following established procedures rather than discussing their own procedural choices, b. they are discussing others' work in contrast to their own, c. they are referring to their own future research, or d. they wish to front (i.e., topicalize) certain information in sentences." (ibid. 68-69) Tarone et alii were pioneers of rhetorical analysis in ESP, as they did not simply state that a particular feature (namely the passive voice) was frequently used in a certain type of text, but they also asked why this specific item was employed, identifying different rhetorical functions. Moreover, they started to take into consideration the differences within larger ESP registers, as they did not refer to the whole range of scientific disciplines, to English for Science, but to a particular branch of it, i.e. astrophysics. Thus, in this second phase the focus of register analysis became more rhetorical, and, when talking about understanding language use in ESP, mere counting of grammatical and/or lexical features was not enough any longer.

The third phase of the evolution of ESP integrated the discoveries of the previous two phases (linguistic features and rhetorical elements), as the focus was on the target situation and the oral communication students may need in different professional contexts, which led to the implementation of the so-called notional-functional curriculum. The main pillars of this notional-functional approach were: the communicative purposes (or functions) of the speaker, the setting for language use and the mode of communication and the keyword of the whole approach is the functional nature of communication. "Therefore in Notional-Functional Syllabuses, instead of having textbook units which are organized grammatically (as in Phase 1), such as The Present Perfect, or which consider the purposes of written discourse (e.g. Article Introductions or The Sales Letter), as in Phase 2, there are chapter headings such as Agreeing and Disagreeing or Paying Compliments. Within the chapters, students are provided with sample dialogues taking place in different contexts among different people, thereby exemplifying the language which realizes a speaker's communicative purposes within a specified context." (ibid. 70) 
The fourth phase started in the second half of the 1980s. If earlier the focus had been on the discourse and its grammatical features, on the communicative situation or the communicative purpose, now the attention shifted to the strategies used by learners to acquire the language (the contribution pf psycholinguistics). Hutchinson and Waters (1987) were the first who claimed that the needs analysis had to include issues like the measurement of the learners' existing knowledge, their interest in the materials presented, the learners' modalities of storing and retrieving information and their active involvement in curriculum design.

More recently, lexicographers and terminologists have started to focus less on the didactic aspects and more on the problem of specialized languages, this time the main question being not necessarily how to teach specialized languages, but what such languages look like. Raquel Martinez Motos (2013) seems to opt for a new term, Academic and Professional Languages, a term created and introduced by Alcaraz in his articles El ingles profesional y academico/ Academic and Professional English (2000), El lenguja de la farmacia. Lexicologia y lexicografia/ The Language of Pharmaceutical Sciences. Lexicology and lexicography (2005) and Consciousness in Life and Law (2007).

The first decade of the 2000s can be called the society of knowledge, as "one of the defining features of this society is interdisciplinarity... And (it) is also characterized by a tendency toward specialization. As a result, both interdisciplinarity and specialization have a great influence on what has been named as Academic and Professional Languages." (Motos 2013: 4) Thus, the term Academic and Professional Languages is the most recent term with which we refer to what has been called technical language, special language, specialized language, language for specific purposes, professional language so far. "This term, coined by Alcaraz, refers to the type of language used by specific knowledge communities or groups of professionals, such as chemists, lawyers, physicians, etc. that share similar values and institutions that use the same genres and terminology to communicate. We are aware of the lack of consensus among scholars regarding the boundaries of concepts transmitted by other terms such as 'Language for Specific Purposes' or 'Specialized Language'. In order to avoid any controversy, the term `Academic and Professional Language` will strictly be used here to refer to any type of language used in specialized communication, in an academic or professional setting and characterized as having a restricted number of users." (ibid. 4)

\section{Linguistic peculiarities of specialized languages}

In order to teach specialized languages, one must know what special language stands for, what its main linguistic features are. Defining the principles that govern the physical world requires a special linguistic code. The language of science(s) is 
precise, clear and unambiguous. Impersonal statements, logical thinking, clear and accurate descriptions prevail, while metaphors, humour or affective connotations are completely absent. According to Crystal (1997), English for Science(s) involves a special vocabulary, which often means a large set of words of Latin or Greek origin, but the development of sciences and new discoveries impose the continuous renewal or enrichment of this scientific vocabulary. There is also a "science-specific" grammar: this means that the language of science prefers very accurate and unambiguous expressions, which leads to a higher rate of repetitive expressions, to the frequent use of relative pronouns (which, that, of which) or adverbials. Linking words that express contradiction, explanation, and conclusion are unavoidable. Such linking words are the conjunctions (and, although, though, since, as), prepositions (despite, during) or adverbs (usually, meanwhile, firstly, secondly).

Scientific texts in English often use long and complex sentences, with complex noun phrases. Another particular feature of scientific English is the use of passive voice, which allows the speaker/writer to be more impersonal, to withdraw from his role of doer and put the emphasis on the experiment or phenomenon that has been carried out or presented. Another aspect that must be mentioned is the use of non-verbal items such as graphics, models, images, tables, etc. Yet, the interpretation or explanation of these non-verbal segments of scientific discourses is verbal. "The methodology of science, with its demand for objectivity, systematic investigation, and exact measurements, has several linguistic consequences. There is an overriding concern for impersonal statement, logical exposition and precise description. Emotional comment, humour, figurative expression, and other aspects of personal language are avoided (except in writing for a lay audience)." (Crystal 1997: 384)

David Crystal also describes the features of science specific grammar, i.e. the large technical vocabulary, largely based on Latin or Greek terms, with a lot of compounds which can be very long, imposing abbreviations for practical use, long sentences with a complex internal structure (sentences based on noun phrases), and the use of passive constructions. Neologisms are inextricably linked to language evolution, thus to special languages. "Moreover, scientific vocabulary requires continual updating in the light of the process of discovery. Science is in fact the main birthplace for new words in a language: in a comprehensive English dictionary, the vast majority of the words would be scientific (or technological) terms, more than 750,000 species of insects have been discovered [...] and if all their names were incorporated into the largest available dictionaries, the books would immediately double in size." (ibid. 384)

M. Teresa Cabré (2003) differentiates specialized languages from artificial languages. In her book entitled Terminology. Theory, Methods and Applications she speaks about special or specialized languages to refer to a set of subcodes (that partially overlap with the subcodes of the general language), each of which 
can be 'specifically' characterized by certain particulars such as subject field, type of interlocutors, situation, speakers' intentions, the context in which a communicative exchange occurs, the type of exchange, etc. According to her, special languages have many features in common with the general language, so that a definition of special languages must include the following characteristics:

a. The distinctive elements of special languages are not isolated phenomena, but rather interrelated sets of characteristics.

b. The purpose of communication is more important than other, complementary functions.

c. The special nature consists of differences in subject field, user knowledge, and area of usage. (Cabré 1999: 62)

In her book, Cabré uses the term special languages meaning a subcode of the general language, characterized by the following features:

1. "Special subject fields are those that are not a part of speakers' general knowledge; they are the object of a specific learning process.

2. Speakers who have this type of knowledge are users of special languages, in other words, subject field experts, although here we make a distinction between originators and recipients of specialized communication. Originators who produce specialized communication must have knowledge of a specific subject field, which they have acquired through training. In contrast, recipients can be other experts or the general public, which passively receives special communication while acquiring knowledge.

3. Communication in special languages is usually formal and occurs in situations governed by professional or scientific criteria.

4. Special languages are characterized by a number of language-based features (units and rules) and text-based features (text and document types).

5. A special language is not a structurally monolithic subset, but rather permits the following variations depending on usage and the communicative situation:

a. The degree of abstraction, which depends on the subject field, the recipients of the information, and the sender's communicative purpose.

b. The communicative purpose, which determines variations in text type.

c. Geographic, historic, and social dialects.

d. Personal style.

6. Special languages share a number of pragmatic and language-based characteristics, thus allowing us to refer to them as a subset of the general language that presents a degree of unity.

7. Special languages are a subset of the language as a whole. They intersect with the general purpose language, with which it not only shares features but also maintains constant exchange of units and conventions." (ibid. 65-66)

The greatest divergences between general language and specialized language are found in the vocabulary. The words in the general language texts are much 
easier to understand for most speakers of the language than those in the special texts. There are three groups of lexemes in special language texts:

a. general language lexical items

b. specific lexical items that can be attributed to a borderline area between general language and special language

c. lexical items specific to special texts, the so-called terminus technicus items.

Technical terms are characterized by univocity and accuracy; they are subject to a higher degree of normalization and standardization. They are used in specific contexts; they are listed in specialized dictionaries or glossaries. "Also known as terminology or subject specific terms, they refer to those lexical units exclusively used by a given knowledge community in a specific domain." (Motos 2013: 9)

Semi-technical terms are subject to polysemy and they are often created due to the extension of meaning through analogy. Their usage is not restricted to specific or scientific contexts; on the contrary, they can be common to several fields. Semitechnical terms are lexical units "that come from the general language but have acquired one or more different meanings when used within a specific area." (ibid. 9)

General vocabulary units are words from the general vocabulary of a language that are used in a specialized context, without losing their original meaning.

Certain structures and categories appear more frequently in special texts than in general language texts:

a. Morphological structures based on Greek or Latin formatives

b. Abbreviations and symbols

c. Nominalizations based on verbs

d. Straightforward sentence structure with little complex subordination.

Certain units and structures characteristic of the general language are not found in special texts: certain affixes (those which are deemed colloquial), some verb forms (the second person forms, imperatives, etc.), some pronouns (second person pronouns), and some sentence types (exclamations, etc.) (Cabré 1999: 74-75).

Yet, Cabré (1999) and Alcaraz (2000) have shown that one cannot assume the monosemic and univocal nature of terms from specialized fields: we simply cannot take it for granted that specialists from a certain field will understand each other without being forced to rely on the help of specialized dictionaries, just because the majority of the terms they use are of Greek and/or Latin origin and because the terminology is standardized according to international bodies' conventions. The explanation is that "not every unit belonging to a specialized area can be labelled as being highly technical and univocal.... Lexical units of any given specialized domain can be classified into three different categories: technical terms, semi-technical terms and general vocabulary frequently used in a specialized domain.” (Motos 2013: 9)

Elena Croitoru (2004) provides a set of criteria that distinguish technical texts, her approach focusing on the translation of specialized languages. Translating 
specialized texts is a process of text taming, which involves the linguistic analysis of the text, but also the consideration of the socio-cultural background. The translation of such texts involves two steps, i.e. decoding the message as a receptor and encoding it for other receptors. Technical translations focus on the first step, as it implies understanding of the peculiarities of technical and scientific discourse, while the latter step involves "the use of adequate terminology, the knowledge of the problems, phenomena, processes, etc. dealt with, and the collaboration with the specialist in the field.” (Croitoru 2004: 22)

Croitoru mentions the following features of scientific English:

- Nominative + infinitive with present and past reference, pointing to both simultaneity and anteriority relationship - it was considered to be, it proved to have been;

- Accusative + infinitive with simultaneity relationship: the Talmud considers wine to be the most efficient;

- preposition +gerund and verbal nouns;

- verbal adjectives;

- gerund as a subject (usually rendered in Romanian by prin faptul că or used after instead of and translated şi nu;

- passive constructions, which have the highest frequency in specialized texts... The use of the subjunctive mood is specific to formal English, hence to specialized texts (ibid. 21). Among other peculiarities she mentions emphatic use which lays stress on a certain element or comparative sentences and comparative constructions, post-modification rendered by the -ing form (wine containing or people suffering from translated into Romanian through attributive clauses vinuri care conțin or oameni care suferă de), or wh-marked relative clauses (separated by a comma from the main clause), which is also a syntactic characteristic of specialized texts.

Marian Aleson's study (2013) links the issue of specialized language to the discourse community that uses it, stating that earlier only the language of science and technology was found scientific enough to become subject to ESP concerns. Nevertheless, "one of the key features that characterize specialized languages is its close relation to the needs of the Discourse Communities that use them." (Aleson 2013: 15)

Aleson relies on the definition offered by Alcaraz when attempting to circumscribe the levels and features of scientific language: "Technical or highly technical vocabulary is still defined as the lexicon belonging to a subject specialty, whereas semi-technical vocabulary consists of words and expressions that belong to the given general-core vocabulary of a language but that are frequently employed on a given specialized field with an added specific sense... Furthermore, specialized lexicon had to comply, as a result, with the ideas of univocity and prescription; that is to say, there is one word (or lexical unit) per concept and a discourse community that prescribes that relation as such." (ibid. 16) 
More recently a significant shift has occurred in the perception and teaching policies of ESP, as the previous reading skill focused tendency has given way to a more modern and rather holistic approach, which takes into account issues of pragmatics (ways of expressing hints, the role of presuppositions), functional grammar (the use of qualitative adjectives and adverbs), and discourse analysis (the use of specific genres in a specific setting and a specific goal). ESP is no longer only an issue of reading and understanding specialized texts from books and manuals. "Vocabulary, for instance, is not just regarded under the two-fold classification of technical and semi-technical language. On the contrary, there is a strong interest by researchers to analyse the non-specific vocabulary from the general-core language that is conventionally employed in specific professional and academic contexts at high frequency rates. Concerning syntax, most of the research done highlights the notion of the existence of certain grammatical and syntactical traits that are more frequently used than others, and reinforces the idea that it is very difficult to find syntactic structures whose use is essentially specific. Thus, ESP with regard to syntax abides by the same syntactic rules of general language, notwithstanding the fact that they establish a certain preference for some structures (...) Consequently, lexicon is given again a preferred status in ESP studies. Summarizing, modern perspectives have gone back to the idea that context in professional and academic settings determine, in a way, the language we use.” (ibid. 18)

The question Lowe asks in his article Characteristics of the Language of Science is whether the language of science is less culture-bound and more special than any other subject. He quotes Strevens, who states that scientific discourse uses a lot of symbols, numbers (largely international in character), a lot of words, roots and affixes of Greek and Latin origin. The features of scientific prose are: rather long sentences containing many clauses and with much embedding; long nominal groups containing strings of adjectives or nouns acting as adjectives each providing greater specificity; frequent passives having the effect of putting important ideas in initial position where in English they carry salience of meaning. Strevens defines scientific English as "simply the English used by scientists or for the purpose of those engaged in science. It has the same grammar, pronunciation and spelling as are found in all kinds of English; it includes much of the general vocabulary of English, though with a large number of specialized items or of familiar words used in specialized ways; it also carries an array of linked symbols and visual symbolizations which nevertheless can be verbalized by those who know the rules for doing so. What then is different or special about scientific English? A brief and oversimplified answer is that the particular mixture of grammatical and vocabulary items typically found in scientific English may display some or all of an array of features, including... long and complicated noun-phrases, a higher proportion of logico-grammatical items, a high proportion of items of specialized vocabulary. Equally important is 
the fact that the argument, the rhetoric, the communicative function of scientific English is chosen so as to serve the particular purposes of the writer or speaker." (Strevens apud Lowe 2009) Thus, the main features of specialized language are logic, linkers and specialized vocabulary.

On the other hand, Robinson (1980) denies the possibility of establishing and clearly differentiating a register of science. "There is broad agreement that scientific English is general English plus the extra components of science. She says that there is a great need for less generalization and greater precision that could account for differences of opinion. Swales, for instance, has advocated that the main verbs in scientific texts are generally in the present simple tense whereas Close emphasizes the continuous form of the verb. A broad agreement that the discourse markers and connectives (link words) are important does seem to exist. [...] though ironically Robinson remarks of connectives that they are important perhaps not because they are special to ESP but because the general ELT has so far ignored them." (Robinson apud Lowe 2009: 4)

Terry Copeck et al. (1997) have attempted to make up an inventory of the features that render a text technical. "When someone calls language technical in everyday life, it is usually understood to mean that its message is hard to grasp. In scientific circles however the modifier has a happier connotation ... researchers generally understand technical text to mean writing which is more tractable because, for example, it lacks figurative language and can be understood in its literal sense." (Copeck et al. 1997: 1)

After presenting some definitions of the term technical text that they have found on the internet, the authors of this article suggest that due to the difficulty of providing a generally accepted definition, we should use the term text technicality instead. Linguists categorize written materials according to genre. Some authors seem to use this term and text type interchangeably [...] is technical text a genre, or a type or something else? [...] We came to the conclusion that technicality is not a genre; that it is a feature of a number of genres." (ibid. 4)

Based on the categories in the international Corpus of English, Copeck and his fellow authors concluded that literal public writing would be roughly synonymous with technical text. (Literal public writing includes the following features: literal = public writing employing the dictionary meanings of words; information = literal writing relating a sequence of events or the particular details of a thing; instruction = literal writing communicating a set of related concepts; persuasion = literal writing developing an argument). Therefore, a minimal definition of technical texts would be the following: "a symbolic record on a medium in a generally-understood system of communication employing glyphs and the rules to combine them. These broadly disseminated records are intended for a general readership; they employ words in their literal sense and assume only objective, generally available knowledge about the world and the domain of discourse." (ibid. 6) 
After conducting the research and analyzing the data, the researchers have formulated a definition of technicality and have removed some of the items from the list, namely the ones that have proved to be weak predictors of technicality. Surprisingly enough, some of the items removed are the ones previous authors mentioned as being features of scientific-ity. Among the weak predictors of technicality, the authors have identified and removed from the list we mention: increasing complexity in the content, grammatical writing, connotative language, examples, complex sentences, passive constructions, and statements of opinion or belief. Additionally, terms defined in the text, non-textual elements (such as figures) and lists have also been found as not relevant for text technicality. Still, despite the removed items, the researchers state that each removed item was a plausible candidate to indicate technicality.

Still, what makes a text technical? According to Copeck's rather long and narrative-like definition, a technical text is a text "quite like to have an identified topic on which it is focused. It will communicate knowledge about that topic in a serious and objective manner, developing its thoughts in a logical, orderly way. This produces a document with hierarchical organization in which information can be accessed at random. Sections in such documents often bear titles or headings. Authors typically use terminology specific to the domain and avoid colloquialism and humour or invective. Their writing is likely to use same-sense domain verbs and to make generic references (talk about classes rather than individuals).

Technical texts frequently have an introduction and a table or contents or index. They may use citations but avoid quoted dialogue. Material may be presented with special fonts or punctuation or according to some commonly understood convention. It avoids vague terms or figurative language and tends to use explicit analogies, unambiguous references and nominalizations.

A number of syntactic characteristics suggest technicality. Technical writing uses few interrogative or imperative sentences, but sentences incorporating some form of 'be' are common. Statements are often couched in the third person and the present tense and employ subordination suggesting cause and effect. Binders and hedges are used to knit the narrative together. Writing can be dense: ellipses are frequent, particles or empathics rare." (ibid. 22)

\section{Conclusions}

It seems obvious that the senior branch of ESP is English for Science and Technology, as it received the biggest amount of attention, it was the first to be included in English teaching curricula, and it has had the greatest number of practitioners and the most numerous volumes of publications. The majority of scientific papers and books have long been printed in English: no wonder that 
Copeck's research has also focused on technical texts and that they use the term technical text in a broad sense. Another explanation of this concentration on EST is that "science, especially at the discourse level, is more regular across languages" (Celce-Murcia 1991: 71), which means that there are many similarities between scientific English and Scientific Romanian, for instance, especially with terms of Latin or Greek origin, names of chemical substances, etc.

Thus, we can conclude that, if in the early years of developing and implementing methods and materials for teaching ESP, the interest was oriented towards English for Science and Technology and English for Business and Economics, in the 1990s a new branch of science emerged and gained importance, thus English for Information Technology and English for the Internet became fashionable. In the 2000s, due to the spread of mass tourism and to the changes that occurred in the labour market, which made more and more people take up jobs (even if only summer jobs) abroad, the need for other "Englishes" grew, and several course books on English for Tourism or English for Medicine, for instance, were published.

The diversification of ESP teaching materials and fields is accompanied by an increase of the interest in the lexis, terminology and grammar of English for Specific Purposes, also called scientific English (Crystal), technical English (Copeck et al), specialized language, special language, specialized communication (Cabré), Professional English or, more recently, Academic and Professional Language (Motos). Specialized communication seems to have become the focus of a wide range of studies and we assume that research in the field of specialized languages will expand in the future.

\section{References}

Alcaraz, E. 2000. El inglés profesional y académico [Professional and Academic English]. Madrid: Alianza Editorial.

Aleson, M. 2013. An overview of the evolution of English lexicography in the industries of leisure and tourism. In Isabel Balteiro (ed.), New Approaches to Specialized English Lexicology and Lexicography, 15-46. Newcastle upon Tyne: Cambridge Scholars Publishing.

Balteiro, I. (ed.). 2013. New Approaches to Specialized English Lexicology and Lexicography. Newcastle upon Tyne: Cambridge Scholars Publishing.

Cabré, T. M. 1999. Terminology. Theory, methods and applications. In: Helmi Sonneveld, Sue Ellen Wright (eds.), Terminology and Lexicography Research and Practice ( $1^{\text {st }}$ ed. 1992 Barcelona, Emuries). Amsterdam/Philadelphia: John Benjamins Publishing Company.

Cabré, T. M. 2003. Terminology. Theory, methods and applications. Terminology 9(2): 163-199. 
Carver, D. 1983. Some propositions about ESP. The ESP Journal 2: 131-137.

Celce-Murcia, M. (ed.) 1991. Teaching English as a Second or Foreign Language. Budapest: Akadémiai Kiadó - Newbury House.

Copeck, T. et al. 1997. What is technical text? Language Sciences 19 (4): 391-423.

Crystal, D. 1997. The Cambridge Encyclopedia of Language. Cambridge: Cambridge University Press.

Croitoru, E. (ed.) 2004. English through Translation. Interpretation and Translation-Oriented Text Analysis. Galați: Editura Fundației Universitare Dunărea de Jos.

Hutchinson, T. - Waters, A. 1987. Developments in ESP. A Multidisciplinary Approach, Cambridge: Cambridge University Press.

Kurtán, Zs. 2003. Szakmai nyelvhasználat [Professional Language Use]. Budapest: Nemzeti Tankönyvkiadó.

Motos, R. M. 2013. The role of interdisciplinarity in lexicography and lexicology. In Isabel Balteiro (ed.), New Approaches to Specialized English Lexicology and Lexicography, 3-13. Newcastle upon Tyne: Cambridge Scholars Publishing.

Robinson, P. S. 1980. English for Specific Purposes: The Present Position. Oxford: Pergamon Press.

Strevens, P. 1988. ESP after twenty years: A re-appraisal. In M. Tickoo (ed.), ESP: State of the Art, 1-13. Singapore: SEAMEO Regional Centre.

Strevens, P. 1976. Problems of learning and teaching science through a foreign language. Studies in Science Education 3: 55-68.

Tarone, E., Dwyer, S., Gillette S., Icke, V. 1981. On the Use of the Passive in Two Astrophysics Journal Papers. ESP Journal 1(2): 123-140.

Widdowson, H.G. 1974. Literary and scientific uses of English. English Language Teaching Journal 28(3): 282-292.

\section{Online resources}

Copeck, T., K. Barker, S. Delisle, S. Szpakovwicz \& J..Delannoy. What is technical text? www.researchgate.net. (12 May 2014)

Gatehouse, K.. Key Issues in English for Specific Purposes (ESP) Curriculum Development, www.khae-service.com (15 March 2011)

Laurence, A. English for Specific Purposes: What does it mean? Why is it different? http://www.antlab.sci.waseda.ac.jp/abstracts/ESParticle.html. (15 March 2011)

Lowe, I.. 2009. Characteristics of the language of science, www.scientifilanguage. com/esp/characteristics-language-science.pdf (10 May 2014) 